\title{
Low genetic variation in the salmon and trout parasite Loma salmonae (Microsporidia) supports marine transmission and clarifies species boundaries
}

\author{
Amanda M. V. Brown ${ }^{1, *}$, Michael L. Kent ${ }^{2}$, Martin L. Adamson ${ }^{1}$ \\ ${ }^{1}$ Department of Zoology, University of British Columbia, 6270 University Boulevard, Vancouver, \\ British Columbia V6T 1Z4, Canada \\ ${ }^{2}$ Department of Microbiology, Oregon State University, 220 Nash Hall, Corvallis, Oregon 97331, USA
}

\begin{abstract}
Loma salmonae is a microsporidian parasite prevalent in wild and farmed salmon species of the genus Oncorhynchus. This study compared ribosomal RNA (rDNA) and elongation factor-1 alpha $(\mathrm{EF}-1 \alpha)$ gene sequences to look for variation that may provide a basis for distinguishing populations. Specimens were collected from laboratory, captive (sea netpen farm and freshwater hatchery) and wild populations of fish. The host range included rainbow trout O. mykiss, Pacific salmon Oncorhynchus spp. and brook trout Salvelinus fontinalis from British Columbia, Prince Edward Island, Canada, from California, Colorado, Idaho, USA and from Chile. Both loci suggested that a variant in $S$. fontinalis (named 'SV') was a separate species. This was supported by the absence of similar variants in the source material (isolated from laboratory-held $O$. tshawytscha) and high divergence $(1.4$ to $2.3 \%$ in the rDNA and EF-1 $\alpha)$ from $L$. salmonae in the type host and locality $(O$. mykiss in California). L. salmonae from freshwater and anadromous Oncorhynchus spp. were distinguished, providing a basis on which to evaluate possible sources of infection and suggesting geographic boundaries are important. Higher genetic variation occurred among samples of freshwater origin and from a sea netpen farm in Chile, suggesting these environments may present greater population diversity. Invariance in rDNA sequence across 17 samples from anadromous salmon in rivers, lakes, ocean, farms and hatcheries supports the hypothesis that marine transmission occurs and effectively prevents population substructuring caused by freshwater transmission.
\end{abstract}

KEY WORDS: Loma salmonae - Microsporidia · Oncorhynchus · Pacific salmon · Salmon farm · Salvelinus fontinalis $\cdot$ rDNA $\cdot$ EF-1 $\alpha$

Resale or republication not permitted without written consent of the publisher

\section{INTRODUCTION}

Loma salmonae (formerly Pleistophora salmonae Putz, Hoffman and Dunbar, 1965) is a pathogen in the gills and other tissues of wild and captive (sea netpen farm and freshwater hatchery) salmonids in both fresh and marine waters. It can cause morbidity and mortality (up to $10 \%$ ) in farmed fish and widespread infections in wild salmonid populations (Magor 1987, Speare et al. 1989, Markey et al. 1994, Bruno et al. 1995, Kent 2000). There is one report of $75 \%$ prevalence of $L$. salmonae in a population of wild yearling rainbow trout Oncorhynchus mykiss in California,
USA (Wales \& Wolf 1955). Since then it has appeared regularly as an epizootic in numerous species of salmon and trout in northwestern and eastern North America, Japan and Europe (Hauck 1984, Bekhti \& Bouix 1985, Kent et al. 1989, Shaw \& Kent 1999, Lovy et al. 2007). Spread of this disease between sea netpens and wild stocks is a potential problem; however, this would occur only for farms rearing Oncorhynchus spp., as Atlantic salmon Salmon salar appear not to be susceptible to this parasite (Shaw et al. 2001). For a parasite with a relatively broad host- and geographic range, one might expect to observe a number of genetically distinct variants. This is particularly important 
since the recent development of a vaccine against L. salmonae (Speare et al. 2007). Non-genetic studies have suggested there may be strains that differ in host preference (e.g. preferring coho and Chinook salmon to brook or rainbow trout) or showing different infection patterns in salmon versus trout (Bader et al. 1998, Shaw et al. 2000a,c, Sánchez et al. 2001b, Ramsay et al. 2002, Lovy et al. 2004, 2006, Kent \& Speare 2005).

The present study examined genetic variation across Loma salmonae from the wild, hatcheries, sea netpen farms and laboratories in British Columbia (BC) and Prince Edward Island (PEI), Canada, in California, Colorado, and Idaho, USA, and in Chile to establish the baseline level of variation that we might expect within this species and to look for genetic variants that may correspond to different populations. Genetic data from the type host, rainbow trout Oncorhynchus mykiss in California, is essential as this parasite species is morphologically indistinguishable across its geographic and host range (Morrison \& Sprague 1983, Shaw et al. 1997, Kent et al. 1998, Brown \& Kent 2002) and distinct strains or cryptic species may exist. For example, some data suggest $L$. salmonae is naturally limited to Oncorhynchus species (Shaw \& Kent 1999, Shaw et al. 2000c), while laboratory transmission studies suggest it could have a broader host range with a variant preferring brook trout Salvelinus fontinalis in PEI (Speare et al. 1998a, Shaw et al. 2000c, Sánchez et al. 2001a, Becker \& Speare 2007). As L. salmonae occurs in all life history phases of all 5 species of wild Pacific salmon Oncorhynchus spp. in BC (Kent et al. 1998, Shaw \& Kent 1999), genetic variants might be expected to mirror the significant substructuring seen in the hosts (Groot \& Margolis 1991), particularly if the parasite's freshwater transmission phase dominates. This general pattern was seen in trematode parasites, for which those limited to freshwater hosts were much more subdivided than those with life histories including a highly mobile terrestrial host (Criscione et al. 2005). Genetic data for L. salmonae from different environments may reveal where there is most genetic diversity and potential for new strains if presented with new selective pressure. For example, 2 studies show greater genetic diversity of salmon and trout parasites (sea lice and haematopoietic necrosis virus) in captivity compared to the wild (Todd et al. 1997, Troyer et al. 2000).

For this study, ribosomal RNA genes (rDNA) and elongation factor-1 alpha (EF-1 $\alpha$ ) gene sequences were chosen because these regions are easily amplified from small amounts of tissue, are extremely wellcharacterized, and tend to show intraspecific variation in Microsporidia and other organisms (Cho et al. 1995, Moreira et al. 1999, Roger et al. 1999, Cheney et al. 2000, Vossbrinck \& Debrunner-Vossbrinck 2005). Past studies show they also have suitable intraspecific vari- ation in the genus Loma (Shaw et al. 1997, Brown \& Kent 2002). Because rDNA may have multiple diverged copies in some species of Microsporidia (O'Mahony et al. 2007), EF-1 $\alpha$ may provide a low-copy number independent marker to contrast with results from rDNA. The genetic sequence data were gathered from $L$. salmonae from laboratory, captive and wild environments to better characterize this species, and to look for variants that may help distinguish populations.

\section{MATERIALS AND METHODS}

Specimen collection. Loma salmonae specimens were collected from a range of hosts, environments and localities (listed in Table 1). Wild Pacific salmon Oncorhynchus spp. were caught by hook and line or seine from rivers, lakes and bays on Vancouver Island or surrounding areas in British Columbia, Canada, or were caught by trawling in Georgia and Johnstone Straits or west coast of Vancouver Island aboard the Canadian Coast Guard Ship 'W.E. Ricker' during Fisheries and Oceans Canada research surveys over 5 yr. Fresh gills were examined at 400 and $1000 \times$ magnification for the presence of $L$. salmonae then placed in $95 \%$ ethanol.

Fishes from commercial marine netpen farms and government hatcheries in Canada, USA, and Chile were examined for Loma salmonae infection on-site by the naked eye or sometimes under a dissection microscope (100 to $250 \times)$ then gills were preserved in $95 \%$ molecular grade ethanol or frozen.

Laboratory-reared Chinook salmon Oncorhynchus tshawytscha were raised at the Pacific Biological Station (PBS), Nanaimo, BC, Canada and maintained as described in Shaw et al. (1998). These fish were initially infected with Loma salmonae from a nearby commercial farm in BC. Laboratory-reared specimens collected over 4 yr (consecutively labeled C-NA1 through C-NA7 in Table 1) were examined microscopically (100 to 400x) for the presence of L. salmonae, and individual gills were fixed in $95 \%$ molecular grade ethanol, or, where spore isolation was to be performed, gills were placed in Earl's Buffered Saline Solution (EBSS) and stored at $4{ }^{\circ} \mathrm{C}$. Laboratory-held brook trout Salvelinus fontinalis gill specimens were provided by Dr. J. Genaro Sánchez-Martinez from the Atlantic Veterinary College, PEI, Canada.

Spore and DNA isolation. DNA isolates from gill preparations were prepared from single fish, except in a few cases (see Table 1) where isolates represent preparations that were also used in other experiments and for which gills had already been pooled from several fish. In the latter cases, each isolate comprised fish of one species, and of the same approximate size (age), 
Table 1. Genetic variants in ribosomal RNA (rDNA) and elongation factor-1 $\alpha$ (EF-1 $\alpha$ ) genes from Loma species from wild and captive salmon and trout (Oncorhynchus spp. and Salvelinus fontinalis) from British Columbia (BC) and Prince Edward Island (PEI), Canada, the USA, and Chile. GenBank accession numbers are from HM626203 to HM626230. M: sampled during marine phase, F: sampled during freshwater phase (e.g. as prespawning, spawning, or freshwater-held broodstock in rivers or lakes). Following genotype, numbers in regular font represent the number of repeated runs of PCR and numbers in italics represent the number of clones

\begin{tabular}{|c|c|c|c|c|c|}
\hline \multirow[t]{2}{*}{ Host } & \multirow[t]{2}{*}{ Locality/environment } & \multirow[t]{2}{*}{ Life history } & \multirow{2}{*}{$\begin{array}{l}\text { Sample } \\
\text { name }\end{array}$} & \multicolumn{2}{|c|}{ Genotypes } \\
\hline & & & & rDNA & EF-1 $\alpha$ \\
\hline O. tshawytscha & Nanaimo, BC/laboratory & Anadromous M & C-NA1 ${ }^{\mathrm{a}}$ & LS-BC (1) & \\
\hline O. tshawytscha & Nanaimo, BC/laboratory & Anadromous M & C-NA2 & LS-BC (1) & \\
\hline O. tshawytscha & Nanaimo, BC/laboratory & Anadromous $\mathrm{M}$ & C-NA3 & LS-BC (2) & EF-BC (1) \\
\hline O. tshawytscha & Nanaimo, BC/laboratory & Anadromous M & $\mathrm{C}-\mathrm{NA} 4^{\mathrm{a}}$ & LS-BC (1) & EF-BC (2) \\
\hline O. tshawytscha & Nanaimo, BC/laboratory & Anadromous M & C-NA5 ${ }^{\mathrm{a}}$ & LS-BC (1) & \\
\hline O. tshawytscha & Nanaimo, BC/laboratory & Anadromous M & $\mathrm{C}-\mathrm{NA} 6^{\mathrm{a}}$ & $\begin{array}{c}\text { LS-BC, LS-NAN1 } \\
(5+1)\end{array}$ & $\mathrm{EF}-1, \mathrm{EF}-2(2)$ \\
\hline O. tshawytscha & Nanaimo, BC/laboratory & Anadromous M & C-NA7 ${ }^{\mathrm{a}}$ & $\begin{array}{c}\text { LS-BC, LS-NAN2, } \\
\text { LS-NAN3, } \\
\text { LS-NAN4 }(1+7)\end{array}$ & $\begin{array}{c}\text { EF-BC, EF-3 } \\
\qquad(1+2)\end{array}$ \\
\hline O. tshawytscha & Indian Bay, BC/netpen farm & Anadromous M & C-IB1 & LS-IB (1) & \\
\hline O. tshawytscha & Indian Bay, BC/netpen farm & Anadromous M & C-IB2 & LS-BC (2) & EF-BC (1) \\
\hline O. tshawytscha & Kuncchin, BC/hatchery & Anadromous F & $\mathrm{C}-\mathrm{KU}$ & LS-BC (2) & EF-BC (1) \\
\hline O. kisutch & Sechelt, BC/netpen farm & Anadromous M & O-SE & LS-BC (1) & \\
\hline O. mykiss & California/hatchery & Freshwater & R-CA1 & LS-CAL1 (4) & \\
\hline O. mykiss & California/hatchery & Freshwater & R-CA2 & LS-CAL2 (1) & EF-BC (1) \\
\hline O. mykiss & Idaho/hatchery & Freshwater & R-ID & LS-BC (1) & \\
\hline O. mykiss & Colorado/hatchery & Freshwater & R-CO1 & $\begin{array}{c}\text { LS-COL1, } \\
\text { LS-COL2 }(1+2)\end{array}$ & \\
\hline O. mykiss & Colorado/hatchery & Freshwater & $\mathrm{R}-\mathrm{CO} 2$ & LS-COL3 (1) & \\
\hline O. kisutch & Chile/netpen farm & Anadromous M & $\mathrm{O}-\mathrm{CH}$ & $\begin{array}{c}\text { LS-BC, LS-CHI1, } \\
\text { LS-CHI2, } \\
\text { LS-CHI3 }(2+4)\end{array}$ & EF-BC (1) \\
\hline O. tshawytscha & Texada Island, BC/wild & Anadromous M & $\mathrm{C}-\mathrm{TX}^{\mathrm{b}}$ & LS-BC (1) & \\
\hline O. kisutch & Barkley Sound, BC/wild & Anadromous M & O-BS & LS-BC (1) & \\
\hline O. kisutch & Cape Mudge, BC/wild & Anadromous M & $\mathrm{O}-\mathrm{CM}^{\mathrm{b}}$ & LS-BC (1) & \\
\hline O. gorbuscha & Ballenas Island, BC/wild & Anadromous M & $\mathrm{P}-\mathrm{BI}^{\mathrm{b}}$ & LS-BC (1) & \\
\hline O. nerka & Great Central Lake, BC/wild & Anadromous F & S-GL & LS-BC (2) & EF-BC (1) \\
\hline O. nerka & Sproat River, BC/wild & Anadromous F & S-SP & LS-BC (3) & $\mathrm{EF}-4(1)$ \\
\hline O. nerka & Stamp River, BC/wild & Anadromous $\mathrm{F}$ & S-SR & LS-BC (1) & \\
\hline O. nerka & Boundary Bay, BC/wild & Anadromous M & $\mathrm{S}-\mathrm{BB}^{\mathrm{b}}$ & LS-BC (1) & \\
\hline O. nerka & Fulton River, BC/wild & Anadromous F & S-FR & LS-BC (1) & EF-BC (1) \\
\hline S. fontinalis & PEI/laboratory & Freshwater & SVB-PE1 & SV-1 (1) & \\
\hline S. fontinalis & PEI/laboratory & Freshwater & SVB-PE2 & SV-1 (1) & \\
\hline S. fontinalis & PEI/laboratory & Freshwater & SVB-PE3 & $\begin{array}{l}\text { SV-1, SV-2, SV-3, } \\
\text { SV-4, SV-5, SV-6, } \\
\text { SV-7, SV-8 (3+5) }\end{array}$ & \\
\hline S. fontinalis & PEI/laboratory & Freshwater & SVB-PE4 & SV-1 (1) & \\
\hline S. fontinalis & PEI/laboratory & Freshwater & SVB-PE5 & SV-1 (1) & SV-EF (1) \\
\hline
\end{tabular}

and caught in the same net at the same time, or raised together in the same laboratory tank.

For isolates where spore purification was not performed, approximately 60 to $65 \mathrm{mg}$ of gill tissue (usually 4 to 8 gill filaments, depending on the size of fish) were taken from a single fish (except in 4 cases, see Table 1). For ethanol-fixed gills, ethanol was removed by soaking $15 \mathrm{~min}$ in lysis buffer $(10 \mathrm{mM}$ Tris, $1 \mathrm{mM}$ EDTA, $10 \mathrm{mM} \mathrm{NaCl}, 1 \%$ sodium dodecyl sulphate [SDS]). For several samples (see Table 1), spore isolation was performed to obtain large quantities of pure
Loma salmonae DNA free of contamination from host DNA for reference and as control in other experiments. In these cases, spores were isolated from laboratoryreared Chinook salmon in batches of 6 to 17 fish per isolation, using Percoll (Sigma) gradients as described in Shaw et al. (1998). For each isolate, gill tissue was autolyzed for 3 to $5 \mathrm{~d}$ in cold EBSS and ground using a Polytron (Luzer) tissue homogenizer. The resulting slurries were mixed with distilled, deionized $\mathrm{H}_{2} \mathrm{O}$ $\left(\mathrm{ddH}_{2} \mathrm{O}\right)$, centrifuged at $2000 \times g$ for $10 \mathrm{~min}$, and the spore pellets were washed, resuspended in $\mathrm{ddH}_{2} \mathrm{O}$ and 
centrifuged at $500 \times g$ for $45 \mathrm{~s}$. The new pellets were resuspended, laid onto a $35 \%$ Percoll gradient and centrifuged to pellet spores. This was repeated twice using 50 and $65 \%$ Percoll gradients. A small sample of each pellet was examined microscopically to confirm that it contained clean spores only. Spores were stored at $-70^{\circ} \mathrm{C}$ in $\mathrm{H}_{2} \mathrm{O}$. Spore concentrates required beadbeating (Docker et al. 1997a) to break open spores before DNA could be isolated. Preparations from beadbeaten spores and whole gill filaments were then digested in lysis buffer with $0.5 \mathrm{mg} \mathrm{ml}^{-1}$ Proteinase $\mathrm{K}$ for 4 to $6 \mathrm{~h}$ at $37^{\circ} \mathrm{C}$ in a rotating incubator. DNA was phenol-chloroform extracted (1 phenol step, 2 phenol: chloroform:isoamyl alcohol 25:24:1 steps, and 1 chloroform:isoamyl alcohol 24:1 step), precipitated in cold $95 \%$ ethanol, washed twice with $70 \%$ ethanol, vacuum dried, resuspended in $40 \mu \mathrm{l}$ distilled water and stored for use at $-20^{\circ} \mathrm{C}$.

Polymerase chain reaction (PCR) for sequencing and cloning. PCR for sequencing of ribosomal RNA (rDNA) and EF-1 $\alpha$ genes was performed in a Perkin Elmer Cetus DNA Thermal Cycler 480 in $25 \mu \mathrm{l}$ reactions with standard PCR buffer, $2.5 \mathrm{mM} \mathrm{MgCl}_{2}$, $0.2 \mathrm{mM}$ dNTP, 15 pmol of each primer, and 1 to $3 \mathrm{U}$ of Taq DNA polymerase (Invitrogen). Conditions were $95^{\circ} \mathrm{C}$ for $1 \mathrm{~min}, 35$ cycles of $95^{\circ} \mathrm{C}$ for $50 \mathrm{~s}, 54^{\circ} \mathrm{C}$ for $30 \mathrm{~s}$ (or as low as $50^{\circ} \mathrm{C}$ for difficult amplifications), $72^{\circ} \mathrm{C}$ for $90 \mathrm{~s}$, and a final extension of $72^{\circ} \mathrm{C}$ for $5 \mathrm{~min}$. For sequencing rDNA, forward primers were: M5P-CAC CAG GTT GAT TCT GCC positions 1 to 18 at 5' end of the small subunit (SSU) (18eMIC in Docker et al. 1997b); Seq1f-CGT TGT AGT TCT AGC AGT positions 719 to 736 in the SSU (provided by M. F. Docker); L7f-ATT AGT GAG ACC TCR GCC positions 1001 to 1019 in the SSU (Loma f, in Shaw et al. 1997). Reverse primers were: SeqR-AAC AGG GAC KYA TTC ATC positions 1218 to 1235 in the SSU (present study); 580R-GGT CCG TGT TTC AAG ACG G positions 1847 to 1865 in the LSU (Vossbrinck et al. 1987). EF-1 $\alpha$ primers had to be designed in the present study by matching conserved regions of the gene using an alignment of a wide range of eukaryote sequences including the microsporidian Glugea plecoglossi and several fungi. These primers amplified about $1120 \mathrm{bp}$ from 43 amino acids downstream of the start codon. Forward primers were: EFZ-TTG CTT CAT TGG NCA CGT MGA position 32 (positions are relative to $G$. plecoglossi); EFX-AGA AAG AGG TAG AGG TAC TT position 143; EFV-GTA CAT ATC GTG GTA TTA position 198. Reverse primers were: EFD-TGC ACC TGT ACT ACY CTN CCN GT position 806; EFW-AAG TCA CAT TTT CAC CTT T position 1203; EFY-CAA TTG CAC CGA TTC CGA C position 1314. PCR products were visualized and excised from 0.8 to $1.5 \%$ agarose Tris-borate-EDTA (TBE) or Tris-acetate-EDTA (TAE) gels, and then freeze-thaw extracted or $\beta$-agarase digested to remove agarose.

Cloning and DNA sequencing. PCR products were sequenced directly in both directions and where there was some ambiguity or polymorphism, PCR and direct sequencing was repeated, and if there was sufficient good quality DNA, products were also cloned and several clones (up to 5) were sequenced. Cloned products were cleaned for ligation using Ultraclean15 MOBIO DNA Purification Kit (BIO/CAN Scientific) and cloned using the TOPO TA Cloning PCR Version 2.1 (Invitrogen) using $0.5 \times$ volume. Clones were screened for presence of the insert in $10 \mu \mathrm{l}$ PCR reactions using Taq DNA Polymerase (Invitrogen) with standard reagents and screening primers M13-20 and M13 Rev (conditions: $94^{\circ} \mathrm{C}$ for $2 \mathrm{~min}, 34$ cycles of $92^{\circ} \mathrm{C}$ for $45 \mathrm{~s}, 55^{\circ} \mathrm{C}$ for $45 \mathrm{~s}, 72^{\circ} \mathrm{C}$ for $1 \mathrm{~min} 30 \mathrm{~s}$, followed by $72^{\circ} \mathrm{C}$ for $5 \mathrm{~min}$ ). Positive clones from master plates were grown in $3 \mathrm{ml}$ of standard Luria-Bertani (LB) culture with $50 \mathrm{mM}$ ampicillin by shaking at $220 \mathrm{rpm}$ at $37^{\circ} \mathrm{C}$ overnight. Plasmids were isolated for sequencing using the Rapid Plasmid Miniprep System (Gibco BRL) following directions of the manufacturer.

Sequencing was performed on the ABI PRISM 377 DNA automated sequencer using BigDye Terminator Version 3.1 fluorescent dye-labeled terminators with forward and reverse primers and PCR conditions as recommended for the Taq terminators. For both direct sequencing and sequences from clones, sequences from both directions were compared to check for Taq polymerase or sequencer errors.

Sequence analysis and phylogenetic analysis. To compare sequence variation among Loma salmonae from different hosts and localities for the 2 gene regions (rDNA and EF-1 $\alpha$ ), sequences were aligned using ESEE Version 3.2s (Eyeball SEquence Editor, by Eric Cabot). In all cases the original sequence output data was carefully re-examined for evidence of sequencer software error or background signal. Where these were likely, sequencing was repeated. Where directly sequenced products with no background signal had a clear double-peak at a site confirmed by sequencing in both directions, this was considered a valid polymorphism and was indicated using the standard degenerate nucleotide code. Polymorphism in this context could represent multiple states within a genome or multiple states within a gill sample. In several samples that were pooled from several fish it could also represent a polymorphism among parasite populations in different hosts. Percent sequence difference was calculated by adding the number of substitutions, the number of indels (regardless of size) and half of the number of polymorphic differences (i.e. giving these a half substitution value), divided by the total number of alignment positions for which both sequences were known. 
Phylogenetic analyses were performed on an rDNA alignment including all unique sequence variants (present study) and 3 nearest relative outgroup taxa for which sequences were available in GenBank (Loma embiotocia AF320310 from shiner perch Cymatogaster aggregata, Loma sp. AF104081 from fourbeard rockling Encelyopus cimbrius and Glugea anomala AF044391 from three-spined stickleback Gasterosteus aculeatus). Maximum parsimony (MP), minimum distance evolution (ME) and maximum likelihood (ML) were performed using PAUP* Version 4.0b10 (Phylogenetic Analysis Using Parsimony; Swofford 2001) and Bayesian inference (BI) was performed using MrBayes v.3.1.2 (Huelsenbeck \& Ronquist 2001). For MP, ME and ML, heuristic searches were done with random stepwise sequence addition and tree bisection and reconnection (TBR) branch swapping with 10 repetitions. For unweighted MP and ME the logDet/paralinear model was used as it performs well with unequal base frequencies, which occurred particularly with outgroup taxa. ML was performed after estimating the best-fit model of evolution under the Akaike Information Criterion (AIC) using Modeltest Version 3.06 (Posada \& Crandall 1998). ML heuristic searches were run using the best-fit model (GTR $+\mathrm{I}+\mathrm{G})$ and parameters estimated from the data to generate a starting tree with neighbor-joining, and then parameters were re-estimated prior to heuristic ML search. Statistical support was assessed by bootstrap re-sampling with 1000 replicates reported on $50 \%$ majority rule trees for ML and ME or 100 replicates for ML by faststep. For BI, the GTR model with gamma-distributed rate variation across sites was used for 2 runs of Markov chain Monte Carlo simulations beginning from random starting trees. Sampling occurred at intervals of 10 generations until the standard deviation reached 0.01 (at 450000 generations) and the first 112500 trees ( $25 \%$ burn-in) were discarded while the remaining were analyzed for posterior probability of clades.

\section{RESULTS}

\section{Intraspecific variation in the rDNA region}

Table 1 shows 31 samples (DNA isolates) for which genetic data were obtained. Length of rDNA sequence obtained was typically 1051 to 1171 bp (20 samples), or sometimes longer (1760 to $1829 \mathrm{bp}, 5$ samples) or shorter ( $500 \mathrm{bp}, 6$ samples), perhaps due to weaker amplification robustness of the 5' end of the SSU (less conserved priming sites) and DNA shearing or inhibitors in some samples.

The most common sequence found in this study was shared by 21 of 31 samples (18 of which bore only this sequence). Almost all of these were from British
Columbia, so this reference rDNA sequence is hereafter referred to as the 'LS-BC' genotype. (Note: because ploidy and sex are unknown in Loma species, the term genotype, rather than haplotype, is used). This rDNA genotype occurred in L. salmonae from 4 of the 5 BC Pacific salmon species (Chinook salmon Oncorhynchus tshawytscha, coho salmon O. kisutch, pink salmon $O$. gorbuscha, and sockeye salmon $O$. nerka) and in both netpen and hatchery samples in $\mathrm{BC}$, all wild samples, 7 laboratory samples from BC, 1 Idaho hatchery sample, and in a netpen sample from Chile. All these represent anadromous (living mostly at sea but breeding in fresh water) Pacific salmon hosts, except the Idaho sample which was from freshwater rainbow trout. However, only a short sequence (572 bp) could be obtained from this specimen.

Repeated PCR runs or clones from a single sample often resulted in identical sequences. This was so for 6 of 11 samples shown in Table 1 (values $>1$ in brackets), representing a total of 15 of 46 clones or repeated PCR runs. Whereas, in 5 of 11 samples, representing 31 of 46 clones or repeated PCR runs, there was intrasample variation ( 2 or more unique sequences from a single sample) (shown in Table 1). Accounting for sequencing effort, variation differed among host environments. For example, variation from brook trout was highest with 8 genotypes per 12 clones or PCR runs (sum of numbers in brackets in Table 1), and next highest among samples from captive fish (hatchery and netpen farms) with 10 genotypes from 22 clones or PCR runs, followed by laboratory fish in Nanaimo with 5 genotypes from 20 clones or PCR runs. Intra-sample variation was lowest among wild BC salmon (1 genotype in 12 clones or PCR runs). Among samples from captive fish, hatchery and netpen farm environments were equal in intra-sample variation (hatchery: 6 genotypes per 12 clones or PCR runs versus netpen farm: 5 genotypes per 10 clones or runs).

Of the 13 samples that differed from pure LS-BC, 5 were from brook trout and 8 from Oncorhynchus spp. The sequences from Loma sp. in brook trout were significantly different in both the SSU and large subunit (LSU) regions from all genotypes in Oncorhynchus spp. Compared to LS-BC, the most common genotype from brook trout Salvelinus frontinalis, SV-1 differed by $1.4 \%$ in the SSU (19 nucleotides across 1830 alignment positions), $2.3 \%$ in the LSU (10.5 nucleotides across 452 alignment positions), Among the 8 genotypes from brook trout, there was low divergence $(0.09 \%$ in the SSU and $0.14 \%$ in the LSU).

The Loma salmonae samples most different from LS$\mathrm{BC}$ were from rainbow trout in Colorado differing by less than $0.1 \%$ in the SSU and less than $0.7 \%$ in the LSU, followed by samples from rainbow trout in California, Idaho, and coho salmon in Chile (see Table 2). 
Colorado, California and Chilean samples and 1 Nanaimo laboratory sample displayed 3 polymorphisms that were shared among one or more samples (boldface in Table 3). Polymorphisms '12', '13' and '14' were shared in 3,4 , and 7 genotypes, respectively, these being mostly from Colorado and California samples. Polymorphism ' 14 ' was also found in 1 genotype each from a Chile and Nanaimo.

Overall intraspecific variation in Loma salmonae was extremely low $(<0.2$ differences per 1000 in the SSU and $<1.2$ differences per 1000 in the LSU). For all samples, across $1829 \mathrm{bp}$ of rDNA (1832 alignment positions representing $1343 \mathrm{bp}$ of the $\mathrm{SSU}, 37 \mathrm{bp}$ of the internal transcribed spacer [ITS], and 452 bp of the LSU) most differences occurred in the LSU, and none in the ITS region (Table 3); thus, percent divergence was higher in the LSU than the SSU region for all samples. For reference, a previously published $L$. salmonae sequence from GenBank (accession number U78736) differed from LS-BC (Table 3) by $0.22 \%$ in the SSU (908 bp), $0.77 \%$ in the LSU (452 bp).

\section{Phylogenetic analysis}

Phylogenetic analysis for the rDNA region from MP, $\mathrm{ME}, \mathrm{ML}$ and $\mathrm{BI}$ methods produced trees that always separated sequences from the present study into 2 clades based on Loma species (Fig. 1). One clade contained all genotypes from L. salmonae (designated LS-)
Table 2. Percent ribosomal DNA (rDNA) sequence difference for Loma species for all samples compared to a reference sequence from British Columbia (denoted 'LS-BC'). Sample names correspond to those shown in Table 1. (Note: internal transcribed spacer [ITS] region of rDNA was invariant both among and between samples except those from brook trout). BC: British Columbia, Canada; PEI: Prince Edward Island, Canada; SV: a L. salmonae-like variant in Salvelinus fontinalis; SSU: small subunit; LSU large subunit. rDNA: nucleotides sequenced (all PCR products or clones)

\begin{tabular}{|c|c|c|c|c|}
\hline \multirow[t]{2}{*}{ Sample } & \multicolumn{2}{|c|}{ No. of rDNA } & \multicolumn{2}{|c|}{$\begin{array}{l}\text { Percent difference } \\
\text { from LS-BC }\end{array}$} \\
\hline & SSU & LSU & SSU & LSU \\
\hline \multicolumn{5}{|c|}{ Across all Loma salmonae samples } \\
\hline & 35320 & 21228 & 0.017 & 0.113 \\
\hline \multicolumn{5}{|c|}{ Non-LS-BC samples from laboratory } \\
\hline C-NA6 (BC) & 4125 & 1482 & 0 & 0.101 \\
\hline C-NA7 (BC) & 6624 & 1877 & 0.045 & 0.160 \\
\hline \multicolumn{5}{|c|}{ Non-LS-BC samples from farms and hatcheries } \\
\hline C-IB1 (Idaho) & 987 & 567 & 0 & 0.176 \\
\hline R-CA1 (California) & 1833 & 1075 & 0.027 & 0.279 \\
\hline R-CA2 (California) & 1129 & 469 & 0 & 0.320 \\
\hline R-CO1 (Colorado) & 1261 & 1441 & 0.079 & 0.659 \\
\hline R-CO2 (Colorado) & 1080 & 672 & 0 & 0.521 \\
\hline $\mathrm{O}-\mathrm{CH}$ (Chile) & 4495 & 1989 & 0.022 & 0.151 \\
\hline \multicolumn{5}{|c|}{ Loma sp. 'SV' from brook trout } \\
\hline SVB-PE (SV-PEI1) & 16776 & 4281 & 1.4 & 2.3 \\
\hline
\end{tabular}

and the other contained all genotypes from Loma sp. from brook trout (designated SV-). Resolution of relationships within these clades was poor, as reflected by

Table 3. Loma salmonae. Differences in ribosomal DNA (rDNA) sequences among samples from wild, laboratory and farm populations, compared to a reference sequence from British Columbia, Canada (Genotype LS-BC). Differences for samples with more than 1 genotype are shown together. Sample names correspond to those shown in Table 1 and some samples produced multiple genotypes. Dots represent nucleotides identical with the reference sequence. Dashes represent gaps in the alignment due to indels. For reference, differences from a previously published L. salmonae rDNA sequence in GenBank (accession number U78736) are also shown. Substitution numbers correspond to the following genotypes: 14,15 (LS-NAN1), 2 (LS-NAN2), 4 (LS-NAN3), 9 (LS-NAN4), 10 (LS-IB), 1,13,14 (LS-CAL1), 13,14 (LS-CAL2), 3,12,13,14 (LS-COL1), 6, 7, 8,12 (LS-COL2), 12,13,14 (LS-COL3), 5,14 (LS-CHI1), 11,14 (LS-CHI2), 16 (LS-CHI3). SSU: small subunit, LSU: large subunit. Shared polymorphisms are indicated by bold letters

\begin{tabular}{|c|c|c|c|c|c|c|c|c|c|c|c|c|c|c|c|c|c|c|c|c|c|c|c|}
\hline \multirow[t]{5}{*}{ Sample } & \multicolumn{15}{|c|}{ - Position in rDNA } & \multirow[b]{2}{*}{$\begin{array}{c}\text { LSU } \\
1\end{array}$} & \multirow[b]{2}{*}{1} & \multirow[b]{2}{*}{1} & \multirow[b]{2}{*}{1} & \multirow[b]{2}{*}{1} & \multirow[b]{2}{*}{1} & \multirow[b]{2}{*}{1} & \multirow[b]{2}{*}{1} \\
\hline & & & & & S - & & 1 & 1 & 1 & 1 & 1 & 1 & 1 & 1 & 1 & & & & & & & & \\
\hline & 3 & 4 & 7 & 7 & 8 & 9 & 1 & 2 & 3 & 4 & 5 & 5 & 5 & 5 & 5 & 6 & 6 & 7 & 7 & 7 & 7 & 8 & 8 \\
\hline & 1 & 6 & 2 & 2 & 9 & 9 & 8 & 5 & 9 & 6 & 0 & 3 & 5 & 5 & 7 & 3 & 6 & 2 & 4 & 6 & 8 & 0 & 2 \\
\hline & 4 & 3 & 5 & 9 & 1 & 8 & 7 & 5 & 9 & 8 & 5 & 6 & 0 & 1 & 6 & 2 & 8 & 5 & 5 & 7 & 6 & 5 & 7 \\
\hline Genotype LS-BC & A & - & A & $\mathrm{C}$ & $\mathrm{C}$ & $\mathrm{A}$ & $\mathrm{T}$ & A & $\mathrm{T}$ & $\mathrm{T}$ & $\mathrm{T}$ & $\mathrm{T}$ & G & $\mathrm{T}$ & $\mathrm{T}$ & $\mathrm{A}$ & - & $\mathrm{Y}$ & A & $\mathrm{T}$ & A & $\mathrm{T}$ & - \\
\hline C-NA6 & . & . & . & . & . & . & . & . & . & . & . & . & . & . & . & . & . & $\mathbf{C}$ & $\mathrm{T}$ & . & . & . & . \\
\hline C-NA7 & . & . & G & . & . & . & $\mathrm{C}$ & . & . & . & . & $\mathrm{C}$ & . & . & . & . & . & . & . & . & . & . & . \\
\hline C-IB1 & & & & & . & . & . & . & . & . & . & . & $\mathrm{C}$ & . & . & . & . & . & . & . & . & . & \\
\hline R-CA1 & W & . & . & . & . & . & . & . & . & . & . & . & . & . & . & . & $\mathbf{T}$ & C & . & . & . & 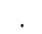 & . \\
\hline R-CA2 & & & & & . & . & . & . & . & . & . & . & . & . & . & . & $\mathbf{T}$ & $\mathbf{C}$ & . & . & . & . & \\
\hline R-CO1 & & & . & A & . & . & . & . & A & W & W & . & . & . & $\mathbf{A}$ & . & $\mathbf{T}$ & $\mathbf{C}$ & . & . & . & . & \\
\hline $\mathrm{R}-\mathrm{CO} 2$ & & & . & . & . & . & . & . & . & . & . & . & . & 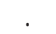 & A & . & $\mathbf{T}$ & C & . & . & . & & . \\
\hline $\mathrm{O}-\mathrm{CH}$ & . & . & . & . & . & 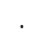 & . & G & . & . & . & . & . & $\mathrm{C}$ & . & . & . & C & . & . & . & $\mathrm{K}$ & . \\
\hline GenBank U78736 & & $\mathrm{C}$ & . & 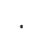 & $\mathrm{Y}$ & $\mathrm{R}$ & . & . & . & . & . & . & . & & . & $\mathrm{R}$ & & $\mathrm{T}$ & & $\mathrm{Y}$ & - & & A \\
\hline Substitution number & 1 & & 2 & 3 & & & 4 & 5 & 6 & 7 & 8 & 9 & 10 & 11 & 12 & & 13 & 14 & 15 & & & 16 & \\
\hline
\end{tabular}


Fig. 1. Maximum parsimony (MP) tree for Loma spp. genotypes (present study) estimated from 1859 alignment positions of ribosomal RNA genes, showing 2 persistent clades for genotypes 'LS-' (Loma salmonae) and 'SV-' (Loma sp. from brook trout). Bootstrap values $>25 \%$ are shown. Genotype names correspond to those shown in Table 1. Outgroup taxa from GenBank: L. embiotocia AF320310 from shiner perch Cymatogaster aggregata, Loma sp. NIL AF104081 from fourbeard rockling Encelyopus cimbrius and Glugea anomala AF044391 from three-spined stickleback Gasterosteus aculeatus. This was one of 998 very similar MP trees. Other analysis methods produced similar trees with the same 2 clades

Loma sp. NIL AF104081

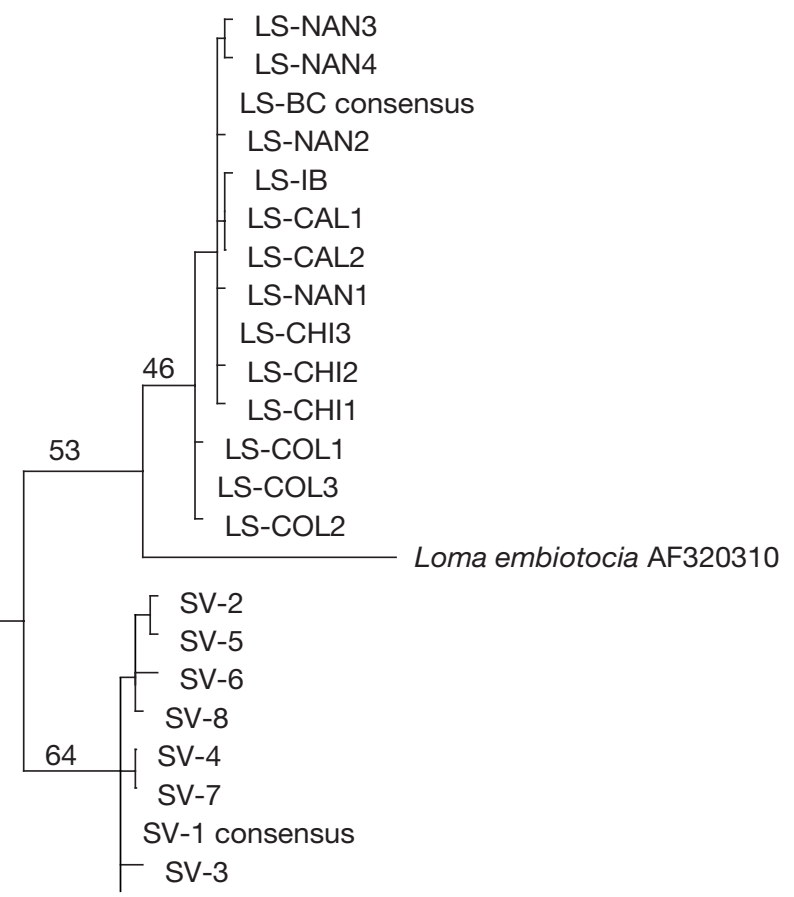

Glugea anomala AF044391
10

$<25 \%$ bootstrap values. Analysis of EF-1 $\alpha$ variation was not performed because sequence variation was so low.

\section{Intraspecific variation in the EF-1 $\alpha$ gene}

Tables $1 \& 4$ show results for the partial EF-1 $\alpha$ gene from 12 samples for which rDNA sequence was also obtained. Sequenced EF-1 $\alpha$ products were 766 to 1069 bp long. Amplification or sequencing was not possible for the remaining samples, perhaps because of DNA quality, inhibitors, or poor priming site match for some samples. The most common sequence found was observed in 6 BC samples, 1 California and 1 Chilean sample. This is referred to hereafter as 'EF$\mathrm{BC}^{\prime}$. Four of 12 samples differed in sequence from EF$\mathrm{BC}_{i} 1$ from brook trout, 2 from the Nanaimo laboratory and 1 was from a wild-caught sockeye in BC. The sequence from brook trout was significantly diverged from EF-BC with $2.3 \%$ difference over 1030 alignment positions. Other samples were only slightly diverged from EF-BC. For example, of 6 substitutional differences from EF-BC, 2 were synonymous and 4 were non-synonymous. Repeated PCR runs or clones from a single sample resulted in identical sequences in 4 of 7 cases, with just 3 cases where more than 1 genotype was found (Table 1).

Overall intraspecific variation in Loma salmonae for the EF-1 $\alpha$ gene was low, at $<0.03 \%$. By comparison all samples were quite diverged from the fish-parasitic microsporidian Glugea plecoglossi (GenBank accession no. D321239) at $28.1 \%$ nucleotide differences over 1132 alignment positions and $14.3 \%$ amino acid differences over 377 amino acid alignment positions plus one 2-amino acid indel compared to the L. salmonae

Table 4. Loma salmonae. Differences in elongation factor-1 alpha $(\mathrm{EF}-1 \alpha)$ DNA sequences among samples from laboratory and wild populations compared to a reference sequence from British Columbia (EF-BC) and Glugea plecoglossi (GenBank accession number D32139). Differences for samples with more than 1 genotype are shown together. Dots represent nucleotides that are identical to those of the reference sequence. Sample names and substitution numbers correspond to those shown in Table 1. Substitution numbers correspond to the following genotypes: 4,5 (EF-1), 6 (EF-2), 1 (EF-3), 2, 3 (EF-4). Synonymous substitutions are indicated by bold letters; others are non-synonymous

\begin{tabular}{|lcccccc|}
\hline \multirow{2}{*}{ Sample } & \multicolumn{7}{c|}{ Position in EF-1 $\alpha$} \\
& 2 & 4 & 4 & 7 & 7 & 8 \\
& 3 & 7 & 9 & 0 & 1 & 1 \\
& 1 & 2 & 1 & 8 & 9 & 4 \\
\hline Genotype EF-BC & A & G & G & A & G & A \\
C-NA6 &. &. &. & T & C & T \\
C-NA7 & T &. &. &. &. &. \\
S-SP &. & C & C &. &. &. \\
GenBank D32139 & T &. & A & T &. & T \\
Substitution number & $\mathbf{1}$ & 2 & 3 & $\mathbf{4}$ & 5 & 6 \\
& & & & & & \\
\hline
\end{tabular}


EF-BC genotype. Between these species there was $14.3 \%$ amino acid difference (>377 amino acid alignment positions).

\section{DISCUSSION}

Genetic characterization of Loma salmonae isolates helps clarify the uniqueness of specimens from brook trout in PEI. The latter were quite genetically diverged from L. salmonae in BC, California, Idaho, Colorado and Chile, and formed a separate phylogenetic clade. Furthermore, the brook trout variant differed in rDNA sequences at a level greater than that found between sibling species of Loma (Shaw et al. 1997, Brown et al. 1998, Brown \& Kent 2002, Brown 2005). This includes that observed between L. salmonae and 2 sister species that were not transmissible to reciprocal hosts (Shaw \& Kent 1999, Shaw et al. 2000a, R. W. Shaw pers. comm.). For example, for SSU and LSU rDNA respectively, compare 1.4 and $2.3 \%$ difference (present study) versus other studies, L. salmonae vs. $L$. embiotocia 0.75 and $1.2 \%$ and L. salmonae vs. Loma sp. from Kent et al. 1998 in lingcod, Ophiodon elongatus, at 1.0 and $1.0 \%$. Similarly, partial EF-1 $\alpha$ sequence difference between $L$. salmonae and the brook trout variant was also greater $(2.3 \%)$ than that between $L$. salmonae samples or between other species pairs in genus Loma (Brown 2005).

More importantly, specimens from brook trout differed genetically from the source from which they were taken, namely Loma salmonae from laboratory-held Chinook in Nanaimo, BC (as described in Sánchez et al. 2001a,b), despite some 40000 rDNA nucleotides sequenced representing infections from over 100 fishes. As well, the brook trout variant differs from western $L$. salmonae in rainbow trout and Pacific salmon in polar filament turns, spore size, virulence and prevalence (Lovy et al. 2004, 2006). These differences caused the authors to name the variants in brook trout and rainbow trout 'SV' and 'OA', respectively. Variant SV spores were only very weakly infective to rainbow trout, the normal host of L. salmonae (Speare et al. 1998a, Sánchez et al. 2001a,b, Speare \& Daley 2003). Past studies (Markey et al. 1994, Bader et al. 1998) also identified Loma-like infections in eastern brook, brown and rainbow trout with spore and xenoma features somewhat different from western L. salmonae.

Taken together, these data strongly suggest the brook trout variant (SV) is a separate species of Loma not from BC. For the SV variant to have been from BC, it would require $\mathrm{BC}$ salmon to harbor a light gill infection with this species that was undetectable through replicated runs of PCR and cloning using several primer combinations. Perhaps more likely, SV could represent a cryptic infection with a Loma species native to brook or rainbow trout from eastern North America. Cryptic infections are expected in Loma species as developmental stages can reside in the heart or other internal organs without formation of xenomas under some temperature conditions (Speare et al. 1998b, Sánchez et al. 1999, 2000, 2001c, Shaw et al. 2001). Furthermore, the molecular tools used previously to identify L. salmonae (PCR-test of Docker et al. 1997a, in situ hybridization, immunohistochemistry with anti-L. salmonae monoclonal antibodies) have not been demonstrated to distinguish it from other Loma species in eastern trout. Indeed, the present results show that the PCR-test of Docker et al. 1997a fails to distinguish SV from L. salmonae because primer sites LS1 and LS2 happen to be invariant between these species, even though substantial genetic differences occur in flanking areas. Thus, the absence of disease, spores, or positive molecular test results in experimental control fishes or naive hatchery specimens in previous studies may not be sufficient to eliminate the possibility of a cryptic infection in these fishes. $L$. fontinalis, described from brook trout with morphology distinct from L. salmonae (Morrison \& Sprague 1983), would be the obvious suspect. While $L$. fontinalis appears to differ slightly from SV (Morrison \& Sprague 1983, Lovy et al. 2004), morphological data for L. fontinalis are not as complete as for SV and there is considerable overlap in ultrastructural features, making definitive comparisons challenging. Genetic differences in the present study should help confirm the identity of infections in future studies.

For all other samples in the present study, sequence data from both rDNA and partial EF- $1 \alpha$ strongly support the integrity of Loma salmonae as a species. Across all western L. salmonae isolates including those from rainbow trout in California (the type host and type locality for L. salmonae), rDNA genotypes clustered together in phylogenetic analysis. Both genetic regions also showed high sequence similarity at a level typical for a microsporidian species. For example, SSU, LSU and EF-1 $\alpha$ differed among samples in the present study at levels from 0 to $0.079 \%, 0.101$ to $0.659 \%$ and about $0.03 \%$, respectively, versus intraspecific variation in homologous regions in other Microsporidia of 0.02 to $0.4 \%$ (SSU), 0.08 to $0.9 \%$ (LSU), and 0.06 to $0.046 \%(\mathrm{EF}-1 \alpha)$ (Gresoviac et al. 2000, Brown \& Kent 2002, Tay et al. 2005, Vossbrinck \& Debrunner-Vossbrinck 2005, Brown 2005, O'Mahony et al. 2007 , Wolinska et al. 2009). This is supported by laboratory experiments (Shaw et al. 2000c) suggesting western variants of $L$. salmonae may infect both anadromous salmon and strictly freshwater rainbow trout, even though the hosts are not presently sympatric through much of their range. 
While Loma salmonae may transmit in both fresh and seawater (Shaw et al. 1998, Shaw \& Kent 1999), if freshwater transmission were dominant then one would expect to see a high degree of population substructuring mirroring that found in the salmon hosts (Groot \& Margolis 1991, Waples et al. 2001). This was not observed. Instead, there was complete rDNA sequence uniformity across wild populations of $L$. salmonae from $\mathrm{BC}$ including marine phases and representative freshwater phases from spawners and prespawners in rivers, lakes and hatcheries. The simplest explanation is that seawater transmission is sufficient to overwhelm any genetic substructuring from transmission in freshwater. Indeed, a seawater transmission phase would seem to be necessary to maintain the high prevalence in salmon at sea (e.g. up to 52\%) (Brown 2005). Two seawater transmission modes are likely, given the path of transmission through the gut (Shaw et al. 1998): inter- and intraspecific piscivory among young salmon (or feeding on tissues from dead fish) in coastal near-shore habitats prior to seaward migrations and seawater transmission by ingestion of free spores (Kent et al. 1989, 1995). The latter mode is supported by evidence suggesting spores can be viable in seawater for up to a year (Shaw et al. 2000b). Another, possibility is that the low overall genetic variation in $L$. salmonae could be the result of recent translocation of this parasite. Whipps et al. (2004) showed no genetic variation between Myxobolus cerebralis from trout in Europe and the USA, suggesting movement of infected trout between continents just a few decades ago. However, low variation in L. salmonae resulting from translocation would be surprising, given how prevalent and widespread L. salmonae is in Pacific salmon.

In several cases multiple genetic variants occurred within a single fish and multiple variants were found within each type of environment in fish in potential sympatry (Nanaimo laboratory, PEI laboratory, netpen farms, hatcheries, and wild fish in BC). This could have implications for control of disease. For example, greater variation in some environments (e.g. captive fish) suggests these populations may hold a greater genetic reservoir with more potential to evolve new, more virulent strains if presented with appropriate selective pressure (Bull et al. 1991, Troyer et al. 2000). It is not known whether this potential could exist in Chile, where the only sample from Pacific salmon with notably higher variation occurred. This infection may have originated from cryptically infected eggs from North America (see evidence of Loma salmonae in farmed salmon ovaries in Docker et al. 1997a).

Sequence variation was greater in Loma salmonae from freshwater (rainbow and brook trout) than from anadromous hosts, supporting the general principle that where isolation is higher, such as in freshwater systems, variation is higher (McCusker et al. 2000, Waples et al. 2001, Criscione \& Blouin 2004, Criscione et al. 2006). This tends to be amplified in farms and hatcheries where fish and parasites may come from numerous sources with historical biogeographic genetic substructuring (Nielsen et al. 1994, Narum et al. 2004, Verspoor et al. 2005). Shared rDNA substitutions (\#12, 13 and 14) differentiating L. salmonae populations further suggest geography might be a significant isolator of this parasite. Gresoviac et al. (2000) found similar results for Nucleospora salmonis, a microsporidium with similar geographic and host-distribution to L. salmonae, where greater rDNA divergence and diversity was observed in rainbow trout than Pacific salmon parasite isolates.

The present study sheds some light on the molecular markers used. For example, low rDNA variance supports previous findings (Brown \& Kent 2002) suggesting that in Loma salmonae rDNA copies may undergo high homogenization that prevents paralog divergence, whereas in other Microsporidia (e.g. Nosema bombi: Tay et al. 2005, O'Mahony et al. 2007; and other Loma spp.: Brown et al. 1998) rDNA paralogs can be numerous and cause problems in comparative population genetic studies. Variation in EF-1 $\alpha$, a gene that is presumably freer from possible paralogs than rDNA, was low enough $(0.03 \%)$ to be similar to that expected from polymerase error (e.g. between $2.0 \times 10^{-5}$ to $2.1 \times$ $10^{-4}$ errors per $\mathrm{bp}$, according to the manufacturer). However, several observations suggest polymerase error was uncommon in these data. First, sequencing both directions helped check for polymerase error. Second, for rDNA data substitutions were either shared among samples (boldface in Table 3) or distributed non-randomly amongst samples (e.g. mostly farm/hatchery), whereas polymerase error would be expected to occur randomly across sequences and among samples. Third, of the 6 EF- $1 \alpha$ substitutional differences, 4 were either at third codon positions or at highly variable amino acid sites by comparison with Glugea plecoglossi and other Loma species (Brown \& Kent 2002, Brown 2005), whereas polymerase error would be more randomly distributed. Furthermore, the 2 laboratory samples with unshared rDNA substitutions were among the few that also possessed EF-1 $\alpha$ substitutions. Thus, while sequence variation in $L$. salmonae appears valid, the low level suggests other population markers (e.g. microsatellites) may be necessary to provide useful information for wild isolates from BC. However, all markers may be affected by genome compaction in the fish-infecting Microsporidia (Nilsen et al. 1998, Cheney et al. 2000, Lom \& Nilsen 2003).

In conclusion, the present study identified genetic variation that may provide a basis for distinguishing 
strains and populations of Loma salmonae with pathogenicity and host preference differences (as reported in Shaw et al. 2000a,c, Ramsay et al. 2002, Kent \& Speare 2005). It also distinguished freshwater resident populations (in Oncorhynchus mykiss) and provided clear evidence that variant 'SV' from brook trout is a separate species. Lastly, this study contributes to the list of studies that have expanded the definition of a microsporidian species to include genetic data from a range of localities and hosts.

Acknowledgements. This work was supported by the Natural Sciences and Engineering Research Council of Canada strategic grant 582073 to M.L.A. We thank S. C. Dawe and the crew aboard the 'W. E. Ricker' for technical assistance in the laboratory and at sea; R. W. Shaw for assistance with collection and rearing of fishes and isolation of spores. J. G. Sánchez-Martinez and D. J. Speare kindly provided material from brook trout. Numerous fish farms and hatcheries kindly provided access to facilities and infected material. P. J. Keeling provided assistance with cloning.

\section{LITERATURE CITED}

Bader JA, Shotts EB, Steffens WL, Lom J (1998) Occurrence of Loma cf. salmonae in brook, brown and rainbow trout from Buford Trout Hatchery, Georgia, USA. Dis Aquat Org 34:211-216

Becker JA, Speare DJ (2007) Transmission of the microsporidian gill parasite, Loma salmonae. Anim Health Res Rev 8: 59-68

Bekhti M, Bouix G (1985) Loma salmonae (Putz, Hoffman et Dunbar, 1965) et Loma diplodae n. sp., microsporidies parasites de branchies de poissons teleosteens: implantation et donnees ultrastructurales. Protistologica 21:47-59

Brown AMV (2005) Molecular evolution, systematics and ecology of microsporidia from fishes and crustaceans. $\mathrm{PhD}$ thesis, University of British Columbia, Vancouver

Brown AMV, Kent ML (2002) Molecular diagnostics for Loma salmonae and Nucleospora salmonis (microsporidia). In: Cunningham CO (ed) Molecular diagnostics of salmonid diseases. Kluwer Academic Publishers, Dordrecht.

Brown AMV, Kent ML, Adamson ML (1998) Phylogeny of microsporidian parasites of fishes reveals dispersed ribosomal RNA genes in relatives of Loma salmonae. In: Program guide and abstracts. 73rd Annual Meeting of the American Society of Parasitologists, 16-20 August 1998, Kona, HI. American Society of Parasitologists, Kona, HI, p 80

Bruno DW, Collins RO, Morrison CM (1995) The occurrence of Loma salmonae (Protozoa: Microspora) in farmed rainbow trout, Oncorhynchus mykiss Walbaum, in Scotland. Aquaculture 133:341-344

Bull JJ, Molineux IJ, Rice WR (1991) Selection of benevolence in a host-parasite system. Evolution 45:875-882

Cheney SA, Lafranchi-Tristem NJ, Canning EU (2000) Phylogenetic relationships of Pleistophora-like microsporidia based on small subunit ribosomal DNA sequences and implications for the source of Trachipleistophora hominis infections. J Eukaryot Microbiol 47:280-287

> Cho S, Mitchell A, Regier JC, Mitter C, Poole RW, Friedlander TP, Zhao S (1995) A highly conserved nuclear gene for low-level phylogenetics: elongation factor- $1 \alpha$ recovers morphology-based tree for heliothine moths. Mol Biol Evol
12:650-656

Criscione CD, Blouin MS (2004) Life cycles shape parasite evolution: comparative population genetics of salmon trematodes. Evolution 58:198-202

Criscione CD, Poulin R, Blouin MS (2005) Molecular ecology of parasites: elucidating ecological and microevolutionary processes. Mol Ecol 14:2247-2257

Criscione CD, Cooper B, Blouin MS (2006) Parasite genotypes identify source populations of migratory fish more accurately than fish genotypes. Ecology 87:823-828

> Docker MF, Devlin RH, Richard J, Khattra J, Kent ML (1997a) Sensitive and specific polymerase chain reaction assay for detection of Loma salmonae (Microsporea). Dis Aquat Org 29:41-48

> Docker MF, Kent ML, Hervio DML, Khattra JS, Weiss LM, Cali A, Devlin RH (1997b) Ribosomal DNA sequence of Nucleospora salmonis Hedrick, Groff and Baxa, 1991 (Microsporea: Enterocytozoonidae): implications for phylogeny and nomenclature. J Eukaryot Microbiol 44: $55-60$

> Gresoviac SJ, Khattra JS, Nadler SA, Kent ML and others (2000) Comparison of small subunit ribosomal RNA gene and internal transcribed spacer sequences among isolates of the intranuclear microsporidian Nucleospora salmonis. J Eukaryot Microbiol 47:379-387

Groot C, Margolis L (1991) Pacific salmon life histories. UBC Press, Vancouver

Hauck AK (1984) Mortality and associated tissue reactions of chinook salmon, Oncorhynchus tshawytscha (Walbaum), caused by the microsporidian Loma sp. J Fish Dis 7: $217-229$

> Huelsenbeck JP, Ronquist F (2001) MRBAYES: Bayesian inference of phylogenetic trees. Bioinformatics 17: $754-755$

Kent ML (2000) Marine netpen farming leads to infections with some unusual parasites. Int J Parasitol 30:321-326

Kent ML, Speare DJ (2005) Review of the sequential development of Loma salmonae (Microsporidia) based on experimental infections of rainbow trout (Oncorhynchus mykiss) and Chinook salmon (O. tshawytscha). Folia Parasitol 52: 63-68

Kent ML, Elliot DG, Groff JM, Hedrick RP (1989) Loma salmonae (Protozoa: Microspora) infections in seawater reared coho salmon Oncorhynchus tshawytscha. Aquaculture 80:211-222

Kent ML, Dawe SC, Speare DJ (1995) Transmission of Loma salmonae (Microsporea) to chinook salmon in sea water. Can Vet J 36:98-101

Kent ML, Traxler GS, Kieser D, Richard J and others (1998) Survey of salmonid pathogens in ocean-caught fishes in British Columbia, Canada. J Aquat Anim Health 10: 211-219

Lom J, Nilsen F (2003) Fish microsporidia: fine structural diversity and phylogeny. Int J Parasitol 33:107-127

> Lovy J, Wadowska DW, Wright GM, Speare DJ (2004) Morphological characterization and notes on the life cycle of a newly discovered variant of Loma salmonae (Putz, Hoffman \& Dunbar) from a natural infection of chinook salmon, Oncorhynchus tshawytscha (Walbaum). J Fish Dis 27:609-616

> Lovy J, Wright GM, Wadowska DW, Speare DJ (2006) Ultrastructural morphology suggesting a new hypothesis for development of microsporidians seen in Loma salmonae infecting the gills of rainbow and brook trout. J Fish Biol 68:450-457

> Lovy J, Wright GM, Speare DJ (2007) Ultrastructural examination of the host inflammatory response within gills of 
netpen reared chinook salmon (Oncorhynchus tshawytscha) with Microsporidial Gill Disease. Fish Shellfish Immunol 22:131-149

Magor BG (1987) First report of Loma sp. (Microsporida) in juvenile coho salmon (Oncorhynchus kisutch) from Vancouver Island, British Columbia. Can J Zool 65:751-752

> Markey PT, Blazer VS, Ewing MS, Kocan KM (1994) Loma sp. in salmonids from the eastern United States: associated lesions in rainbow trout. J Aquat Anim Health 6:318-328

McCusker MR, Parkinson E, Taylor EB (2000) Mitochondrial DNA variation in rainbow trout (Oncorhynchus mykiss) across its native range: testing biogeographical hypotheses and their relevance to conservation. Mol Ecol 9: 2089-2108

> Moreira D, Le Guyader H, Philippe H (1999) Unusually high evolutionary rate of the elongation factor $1 \alpha$ gene from the ciliophora and its impact on the phylogeny of eukaryotes. Mol Biol Evol 16:234-245

> Morrison CM, Sprague V (1983) Loma salmonae (Putz, Hoffman and Dunbar, 1965) in the rainbow trout, Salmo gairdneri Richardson, and L. fontinalis sp. nov. (Microsporidia) in the brook trout, Salvelinus fontinalis (Mitchill). J Fish Dis 6:345-353 57

> Narum SR, Contor C, Talbot A, Powell MS (2004) Genetic divergence of sympatric resident and anadromous forms of Oncorhynchus mykiss in the Walla Walla River, U.S.A. J Fish Biol 65:471-488

> Nielsen JL, Gan C, Thomas WK (1994) Differences in genetic diversity for mitochondrial DNA between hatchery and wild population of Oncorhynchus. Can J Fish Aquat Sci 51(Suppl 1):290-297

> Nilsen F, Endresen C, Hordvick I (1998) Molecular phylogeny of microsporidians with particular reference to species that infect the muscles of fish. J Eukaryot Microbiol 45:535-543

O'Mahony EM, Tay WT, Paxton RJ (2007) Multiple rRNA variants in a single spore of the microsporidian Nosema bombi. J Eukaryot Microbiol 54:103-109

Posada D, Crandall KA (1998) MODELTEST: testing the model of DNA substitution. Bioinformatics 14:817-818

Putz RE, Hoffman GL, Dunbar CE (1965) Two new species of Pleistophora (Microsporidia) from North American fish with a synopsis of Microsporidia of freshwater and euryhaline fishes. J Protozool 12:228-236

Ramsay JM, Speare DJ, Dawe SC, Kent ML (2002) Xenoma formation during microsporidial gill disease of salmonids caused by Loma salmonae is affected by host species (Oncorhynchus tshawytscha, O. kisutch, O. mykiss) but not by salinity. Dis Aquat Org 48:125-131

Roger AJ, Sandblom O, Doolittle WF, Philippe H (1999) An evaluation of elongation factor $1 \alpha$ as a phylogenetic marker for eukaryotes. Mol Biol Evol 16:218-233

Sánchez JG, Speare DJ, Markham RJF (1999) Nonisotopic detection of Loma salmonae (Microspora) in rainbow trout (Oncorhynchus mykiss) gills by in situ hybridization. Vet Pathol 36:610-612

Sánchez JG, Speare DJ, Markham RJF (2000) Normal and aberrant tissue distribution of Loma salmonae (Microspora) within rainbow trout, Oncorhynchus mykiss (Walbaum), following experimental infection at water temperatures within and outside of the xenoma-expression temperature boundaries. J Fish Dis 23:235-242

Sánchez JG, Speare DJ, Markham RJF, Jones SRM (2001a) Experimental vaccination of rainbow trout against Loma salmonae using a live low-virulence variant of L. salmonae. J Fish Biol 59:442-448

Sánchez JG, Speare DJ, Markham RJF, Jones SRM (2001b) Isolation of a Loma salmonae variant: biological character- istics and host range. J Fish Biol 59:427-441

Sánchez JG, Speare DJ, Markham RJF (2001c) Altered tissue distribution of Loma salmonae: effects of natural and acquired resistance. J Fish Dis 24:33-40

Shaw RW, Kent ML (1999) Fish microsporidia. In: Wittner M, Weiss LM (eds) The microsporidia and microsporidiosis. American Society for Microbiology Press, Washington, DC, p 418-446

Shaw RW, Kent ML, Docker MF, Brown AMV, Devlin RH, Adamson ML (1997) A new species of Loma (Microsporea) in shiner perch (Cymatogaster aggregata). J Parasitol 83: 296-301

Shaw RW, Kent ML, Adamson ML (1998) Modes of transmission of Loma salmonae (Microsporidia). Dis Aquat Org 33: 151-156

Shaw RW, Kent ML, Adamson ML (2000a) Innate susceptibility differences in chinook salmon Oncorhynchus tshawytscha to Loma salmonae (Microsporidia). Dis Aquat Org 43:49-53

Shaw RW, Kent ML, Adamson ML (2000b) Viability of Loma salmonae (Microsporidia) under laboratory conditions. Parasitol Res 86:978-981

> Shaw RW, Kent ML, Brown AMV, Whipps CM, Adamson ML (2000c) Experimental and natural host specificity of Loma salmonae (Microsporidia). Dis Aquat Org 40:131-136

Shaw RW, Kent ML, Adamson ML (2001) Phagocytosis of Loma salmonae (Microsporidia) spores in Atlantic salmon (Salmo salar), a resistant host, and chinook salmon (Oncorhynchus tshawytscha), a susceptible host. Fish Shellfish Immunol 11:91-100

Speare DJ, Daley J (2003) Failure of vaccination in brook trout Salvelinus fontinalis against Loma salmonae (Microspora). Fish Pathol 38:27-28

Speare DJ, Brackett J, Ferguson HW (1989) Sequential pathology of the gills of coho salmon with a combined diatom and microsporidian gill infection. Can Vet J 30: 571-575

Speare DJ, Arsenault GJ, Buote MA (1998a) Evaluation of rainbow trout as a model for use in studies on pathogenesis of the branchial microsporidian Loma salmonae. Contemp Top Lab Anim Sci 37:55-58

Speare DJ, Beaman HJ, Jones SRM, Markham RJF, Arsenault GJ (1998b) Induced resistance in rainbow trout, Oncorhynchus mykiss (Walbaum), to gill disease associated with the microsporidian gill parasite Loma salmonae. J Fish Dis 21:93-100

Speare DJ, Markham RJF, Guselle NJ (2007) Development of an effective whole-spore vaccine to protect against microsporidial gill disease in rainbow trout (Oncorhynchus mykiss) by using a low-virulence strain of Loma salmonae. Clin Vaccine Immunol 14:1652-1654

Swofford DL (2001) PAUP*. Phylogenetic Analysis Using Parsimony ( ${ }^{*}$ and other Methods). Version 4. Sinauer Associates, Sunderland, MA

> Tay WT, O'Mahony EM, Paxton RJ (2005) Complete rRNA gene sequences reveal that the microsporidium Nosema bombi infects diverse bumblebee (Bombus spp.) hosts and contains multiple polymorphic sites. J Eukaryot Microbiol 52:505-513

Todd CD, Walker AM, Wolff K, Northcott SJ and others (1997) Genetic differentiation of populations of the copepod sea louse Lepeophtheirus salmonis (Kroyer) ectoparasitic on wild and farmed salmonids around the coasts of Scotland: evidence from RAPD markers. J Exp Mar Biol Ecol 210:251-274

> Troyer RM, LaPatra SE, Kurath G (2000) Genetic analyses reveal unusually high diversity of infectious haematopoi- 
etic necrosis virus in rainbow trout aquaculture. J Gen Virol 81:2823-2832

Verspoor E, Beardmore J, Consuegra S, Garcia De Leaniz C and others (2005) Population structure in the Atlantic salmon: insights from 40 years of research into genetic protein variation. J Fish Biol 67 (Suppl A):3-54

- Vossbrinck CR, Debrunner-Vossbrinck BA (2005) Molecular phylogeny of the Microsporidia: ecological, ultrastructural and taxonomic considerations. Folia Parasitol (Praha) 52: $131-142$

Vossbrinck CR, Maddox JV, Friedman S, Debrunner-Vossbrinck BA, Woese CR (1987) Ribosomal RNA sequence suggests microsporidia are extremely ancient eukaryotes. Nature 326:411-414

Editorial responsibility: Dieter Steinhagen,

Hannover, Germany
Wales J, Wolf H (1955) Three protozoan diseases of trout in California. Calif Fish Game 41:183-187

Waples RS, Gustafson RG, Weitkamp LA, Myers JM and others (2001) Characterizing diversity in salmon from the Pacific Northwest. J Fish Biol 59(Suppl A):1-41

Whipps CM, El-Matbouli M, Hedrick RP, Blazer V, Kent ML (2004) Myxobolus cerebralis internal transcribed spacer 1 (ITS-1) sequences support recent spread of the parasite to North America and within Europe. Dis Aquat Org 60: 105-108

Wolinska J, Geissler S, Koerner H (2009) Molecular identification and hidden diversity of novel Daphnia parasites from European lakes. Appl Environ Microbiol 75: 7051-7059

Submitted: December 28, 2009; Accepted: May 21, 2010 Proofs received from author(s): July 6, 2010 